\title{
Potentiation of atracurium by pancuronium and \\ d-tubocurarine
}

H.R. Gerber MD, J. Romppainen MD, W. Schwinn MD
In 60 adult patients undergoing general surgical procedures, the effect of pancuronium or d-tubocurarine "pretreatment" on the injection of a $0.1 \mathrm{mg} \cdot \mathrm{kg}^{-1}$ bolus of atracurium was measured in two separate studies. In study I, the patients received either $0.5 \mathrm{mg}$ ( $\sim 0.007$ $\left.\mathrm{mg} \cdot \mathrm{kg}^{-1}\right)$ or $1.0 \mathrm{mg}\left(\sim 0.015 \mathrm{mg} \cdot \mathrm{kg}^{-1}\right)$ pancuronium, or placebo (saline) three minutes before the injection of atracurium $0.1 \mathrm{mg} \cdot \mathrm{kg}^{-1}$. In study 2, the patients received $0.05 \mathrm{mg} \cdot \mathrm{kg}^{-1}$ or $0.1 \mathrm{mg} \cdot \mathrm{kg}^{-1} \mathrm{~d}$-tubocurarine, or a placebo. The degree of neuromuscular blockade was assessed by evoked mechanogram (adductor pollicis muscle) using supramaximal train-of-four stimulation. Patients receiving pancuronium or d-tubocurarine pretreatment (equal to an $E D_{5}-E D_{15}$ dose) showed significantly greater inhibition of twitch $\left(E D_{70}-E D_{80}\right)$ and train-of-four ratio compared with the placebo groups $\left(E D_{35}-E D_{40}\right)$. Pretreatment with the larger dose of d-tubocurarine $\left(0.1 \mathrm{mg} \cdot \mathrm{kg}^{-1}\right)$ was associated with significant neuromuscular blockade. It is concluded that pancuronium and d-tubocurarine pretreatments potentiate the clinical action of $0.1 \mathrm{mg} \cdot \mathrm{kg}^{-1}$ atracurium in man by $35-100$ per cent.

\section{Key words}

NEUROMUSCULAR RELAXANTS: atracurium, d-tubocurarine, pancuronium, pretreatment; NEUROMUSCULAR BLOCKADE; potentiation.

From the Department of Anaesthesia, University of Basel/Kantonsspital, Basel, Switzerland.

Address correspondence to: Dr. Helmut R. Gerber, Department of Anaesthesia, University of Basel/ Kantonsspital, CH-4031 Basel, Switzerland.
Atracurium was developed in the search for a short-acting compound that might finally replace succinylcholine. However, although atracurium has some unique and desirable features, such as an enzyme independent breakdown mechanism, the rate of onset of the neuromuscular blockade with a dose of $0.3-0.5 \mathrm{mg} \cdot \mathrm{kg}^{-1}$ is significantly slower than following normal clinical doses of succinylcholine. ${ }^{1-3}$

Two procedures have been suggested to enhance the neuromuscular properties of atracurium. One involves the administration of a divided dose with injection of about 25 per cent of the total intubating dose several minutes prior to the actual intubating dose. ${ }^{3,4}$ The second involves the administration of a small "pretreatment" dose of a non-depolarising muscle relaxant other than atracurium several minutes prior to the injection of the intubating dose of atracurium. ${ }^{5}$ In both procedures the enhancement of the action of atracurium could only be evaluated in terms of onset time of maximal neuromuscular blockade as greater than $\mathrm{ED}_{95}$ dosages of atracurium were used.

Thus the purpose of this study was to evaluate the action of a small dose of atracurium that would allow quantitation of the onset time and degree of neuromuscular blockade as well as of its enhancement following "pretreatment" with either a small dose of pancuronium or d-tubocurarine.

\section{Methods}

After having given informed consent, 60 elective adult patients, ASA physical status I, undergoing general surgical procedures, were investigated in two separate studies. Exclusion criteria were pregnancy, medication other than analgesics, body weight deviating more than 20 per cent from normal and age under 18 or over 65 . The studies were approved by the Ethical Committee of the Depart- 
ments of Surgery and Anaesthesia of the University Hospital/Kantonsspital, Basel.

The patients were premedicated one hour prior to induction with morphine $0.01 \mathrm{mg} \cdot \mathrm{kg}^{-1}$ and scopolamine $0.2-0.3 \mathrm{mg}$ intramuscularly. After arrival in the operating room, a $16 \mathrm{~g}$ peripheral plastic cannula was placed and an infusion with Ringer's acetate started. Anaesthesia was induced with thiopentone $\left(4-6 \mathrm{mg} \cdot \mathrm{kg}^{-1}\right)$ and fentanyl $\left(1-2 \mu \mathrm{g} \cdot \mathrm{kg}^{-1}\right)$ intravenously and maintained during the first part of the investigation with 60 per cent nitrous oxide in oxygen using intermittent positive pressure ventilation via a face mask.

In each of the studies, patients were allocated in a random double blind fashion to one of three groups $(\mathrm{n}=10)$ :

\section{Study 1 Group I Pretreatment with $0.5 \mathrm{mg}$ pancuronium \\ Group II Pretreatment with $1.0 \mathrm{mg}$ pancuronium \\ Group III Pretreatment with placebo $(\mathrm{NaCl})$}

Study 2 Group I Pretreatment with $0.05 \mathrm{mg} \cdot \mathrm{kg}^{-1} \mathrm{~d}$-tubocurarine

Group II Pretreatment with $0.1 \mathrm{mg} \cdot \mathrm{kg}^{-1} \mathrm{~d}$-tubocurarine

Group III Pretreatment with placebo $(\mathrm{NaCl})$

To measure the evoked mechanogram, cutaneous electrodes were placed at the right wrist for ulnar nerve stimulation (Myotest, Biometer, Odense DK). Tr. resulting force of thumb adduction was measured with a force displacement transducer and recorder, setting and controlling the preload at $0.3 \mathrm{kp}$ (Myograph 2000, Biometer, Odense DK). ${ }^{6}$ Baseline recordings were made with supramaximal square wave pulses of $0.2 \mathrm{msec}$ duration at a rate of $1 \mathrm{~Hz}$ and the gain adjusted to the 100 per cent response set at $25 \mathrm{~mm}$ on the recording chart. Then the stimulation pattern was changed to the train-offour (four $2 \mathrm{~Hz}$ stimuli at $0.2 \mathrm{msec}$ every $10 \mathrm{sec}$ ). When there was an increase in the train-of-four response during the control registration, the highest point was taken to judge any neuromuscular depression.

After a stable train-of-four recording had been obtained, a $1 \mathrm{ml}$ bolus containing the pretreatment drug or saline as placebo was injected into the peripheral fast running Ringer's acetate infusion. Three minutes after this pretreatment, a 0.1 $\mathrm{mg} \cdot \mathrm{kg}^{-1}$ bolus of atracurium was given. When maximal mechanical twitch and train-of-four depression had been reached, a single venous blood sample was drawn from the right internal jugular vein for determination of the acid base status. The time interval between injection and maximal twitch depression was defined as onset time.

Analysis of variance and Scheffe's procedure for multiple comparisons between the pretreatment groups and placebo group with a range for the 0.05 level were used to compare neuromuscular transmission data. To compare data within the groups, the two tailed t-test as well as the Wilcoxon signed rank test was used. The results are expressed in percentages of control or as ratio of the fourth $2 \mathrm{~Hz}$ stimulus to the first $2 \mathrm{~Hz}$ stimulus in the train-offour. The significance level was $\mathrm{p} \leqq 0.05$.

\section{Results}

The patient groups in both studies were comparable in age, body weight, physical status, sex, doses of thiopentone and fentanyl and acid base status (Table I).

\section{Study 1: pancuronium pretreatment (Table II and Figure 1)}

With the pancuronium pretreatments, patients in Groups I and II received an average dose ( \pm SD) of $0.0075 \mathrm{mg} \cdot \mathrm{kg}^{-1}( \pm 0.0011)$ and $0.0150 \mathrm{mg} \cdot \mathrm{kg}^{-1}$ $( \pm 0.0020)$ respectively.

The twitch height remained unchanged, but the train-of-four ratio $\left(\mathrm{T}_{4} / \mathrm{T}_{1}\right)$ decreased slightly after pretreatment in Group I from 0.97 to 0.95 (range: $0.89-1.0$ ) and in Group II from 1.0 to 0.92 (range: $0.43-1.0$; nine patients had a $T_{4} / T_{1}$ ratio of 0.88 to 1.0: one patient had a $T_{4} / T_{1}$ ratio of 0.43 after pretreatment). These differences were not significant.

After administration of $0.1 \mathrm{mg} \cdot \mathrm{kg}^{-1}$ atracurium, the first twitch in the train-of-four response decreased to 30 per cent in Group I, 24 per cent in Group II and 64 per cent in Group III (control group). The difference between the pretreatment groups and the control group was significant (Groups I vs III, $\mathrm{p}<0.05$, Groups II vs III, $\mathrm{p}<$ 0.05 ). The train-of-four ratio at the time of maximal 
TABLE I Demographic data on the patient population and information related to induction of anaesthesia*

\begin{tabular}{|c|c|c|c|}
\hline Variable & $\begin{array}{l}\text { Group I } \\
n=10\end{array}$ & $\begin{array}{l}\text { Group II } \\
n=I 0\end{array}$ & $\begin{array}{l}\text { Group III } \\
n=10\end{array}$ \\
\hline Age (yr) & $38 \pm 7.4$ & $44 \pm 12.4$ & $46 \pm 14.7$ \\
\hline Weight (kg) & $66.5 \pm 10.6$ & $69.2 \pm 8.4$ & $70.0 \pm 10.3$ \\
\hline Height $(\mathrm{cm})$ & $171 \pm 7.1$ & $168 \pm 8.2$ & $169 \pm 7.1$ \\
\hline $\operatorname{Sex}(M / F)$ & $5 / 5$ & $7 / 3$ & $6 / 4$ \\
\hline Thiopentone $\left(\mathrm{mg} \cdot \mathrm{kg}^{-1}\right)$ & $6.0 \pm 1.3$ & $5.9 \pm 1.3$ & $6.1 \pm 1.12$ \\
\hline Fentanyl $\left(\mu \mathrm{g} \cdot \mathrm{kg}^{-1}\right)$ & $1.9 \pm 0.9$ & $1.9 \pm 0.81$ & $1.9 \pm 0.6$ \\
\hline Venous $\mathrm{pH}$ & $7.36 \pm 0.03$ & $7.36 \pm 0.04$ & $7.34 \pm 0.06$ \\
\hline $\mathrm{PvCO}_{2}(\mathrm{Kpa}) \dagger$ & $5.8 \pm 1.1$ & $6.0 \pm 0.71$ & $6.6 \pm 1.43$ \\
\hline
\end{tabular}

Study 2: d-Tubocurarine pretreatment

\begin{tabular}{lccc}
\hline Variable & $\begin{array}{l}\text { Group I } \\
n=10\end{array}$ & $\begin{array}{l}\text { Group } I I \\
n=10\end{array}$ & $\begin{array}{l}\text { Group III } \\
n=10\end{array}$ \\
\hline Age $(\mathrm{yr})$ & $42 \pm 8.4$ & $44 \pm 4.7$ & $42 \pm 11.2$ \\
Weight $(\mathrm{kg})$ & $73.3 \pm 11.2$ & $74.1 \pm 12.0$ & $69.6 \pm 13.8$ \\
Height $(\mathrm{cm})$ & $175 \pm 7.9$ & $173 \pm 8.4$ & $171 \pm 6.7$ \\
Sex $(\mathrm{M} / \mathrm{F})$ & $7 / 3$ & $7 / 3$ & $6 / 4$ \\
& & & \\
Thiopentone $\left(\mathrm{mg}^{-} \cdot \mathrm{kg}^{-1}\right)$ & $6.3 \pm 0.85$ & $7.6 \pm 1.6$ & $6.8 \pm 1.5$ \\
Fentanyl $\left(\mu \mathrm{g} / \mathrm{kg}^{-1}\right)$ & $2.1 \pm 0.42$ & $1.9 \pm 0.60$ & $2.1 \pm 0.58$ \\
Venous pH & $7.35 \pm 0.05$ & $7.37 \pm 0.04$ & $7.39 \pm 0.07$ \\
PvCO $(\mathrm{Kpa}) \dagger$ & $6.1 \pm 0.9$ & $6.2 \pm 0.79$ & $5.7 \pm 1.21$ \\
\hline
\end{tabular}

Values are expressed as mean \pm SD.

*There was no statistical difference between the groups.

$\dagger \mathrm{Kpa}=7.6 \mathrm{mmHg}$.

TABLE II Effect of pancuronium (P) pretreatment on extent and time course of neuromuscular blockade after $0.1 \mathrm{mg} \cdot \mathrm{kg}^{-1}$ atracurium

\begin{tabular}{llll}
\hline & $\begin{array}{l}\text { Group I } \\
(p=0.5 \mathrm{mg})\end{array}$ & $\begin{array}{l}\text { Group II } \\
(p=1.0 \mathrm{mg})\end{array}$ & $\begin{array}{l}\text { Group III } \\
\text { (control) }\end{array}$ \\
\hline $\mathrm{T}_{4} / \mathrm{T}_{1}$ ratio control & $0.97 \pm 0.04$ & $1.0 \pm 0.01$ & $0.97 \pm 0.04$ \\
$\mathrm{~T}_{4} \mathrm{~T}_{1}$ ratio 3 minutes \\
$\quad \begin{array}{l}\text { after pretreatment } \\
\text { Maximal depression of }\end{array}$ & $0.95 \pm 0.03$ & $0.92 \pm 0.18$ & $0.99 \pm 0.03$ \\
$\begin{array}{l}\mathrm{T}_{1}(\% \text { of control) } \\
\begin{array}{c}\text { Maximal depression of } \\
\quad \mathrm{T}_{4} / \mathrm{T}_{1} \text { ratio }\end{array}\end{array}$ & $30.4 \pm 19.1^{*}$ & $24.4 \pm 28.4^{*}$ & $64.2 \pm 21.2$ \\
$\begin{array}{c}\text { Time to maximal } \\
\text { depression of } \mathrm{T}_{1}(\mathrm{sec})\end{array}$ & $0.20 \pm 0.1^{*}$ & $0.17 \pm 0.15^{*}$ & $0.38 \pm 0.16$ \\
\hline
\end{tabular}

Vulues are expressed as mean \pm SD.

*Significantly different $(p<0.05)$ from control (Group III). 


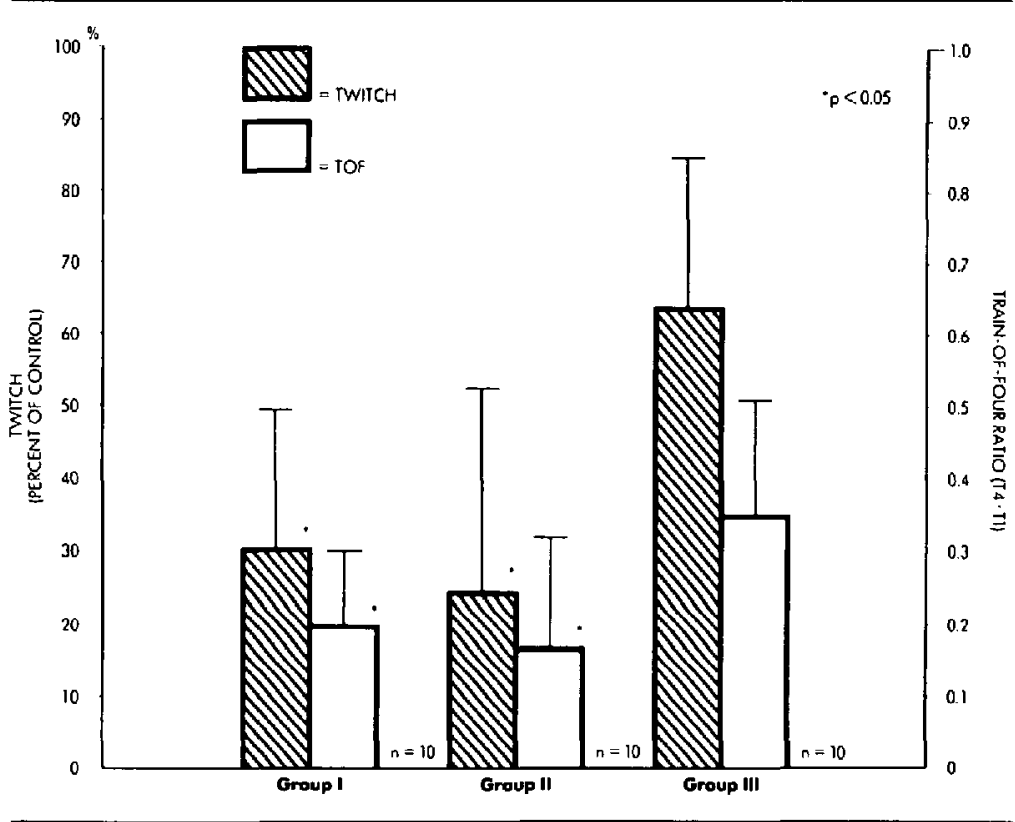

FIGURE 1 Extent of neuromuscular blockade after $0.1 \mathrm{mg} \cdot \mathrm{kg}^{-1}$ atracurium monitored by the evoked mechanical train-of-four response of the adductor pollicis muscle with and without pancuronium pretreatment (Group I: $0.5 \mathrm{mg}$, Group II: $1.0 \mathrm{mg}$ ). Values are expressed as mean \pm SD. *Indicates statistically significant difference from control (Group III).

twitch inhibition was 0.20 (Group I), 0.17 (Group II) and 0.38 (Group III). The differences between the pretreatment groups and the control group were significant.

The time to maximal inhibition (mean \pm SEM) of the first twitch in the train-of-four response $\left(T_{1}\right)$ was $281 \pm 20 \mathrm{sec}, 261 \pm 23 \mathrm{sec}$, and $331 \pm 21 \mathrm{sec}$ in Groups I, II and III, respectively. The difference between Groups II and III was significant.

\section{Study 2: d-tubocurarine pretreatment}

(Table III and Figure 2)

In Group I, the train-of-four ratio decreased slightly from 0.98 to 0.92 after pretreatment (range: 0.67 1.0). This difference was only significant in Group II with a decrease of the train-of-four ratio from 1.0 to 0.75 (range: $0.38-0.93$ ).

After the administration of $0.1 \mathrm{mg} \cdot \mathrm{kg}^{-1}$ bolus, the first twitch in the train-of-four decreased to 20 per cent in Group I, 24 per cent in Group II and 60 per cent in Group III. Again the differences between the pretreatment groups and the control group were significant. The train-of-four ratio at the time of maximal twitch inhibition was 0.19 (Group I), 0.14 (Group II) and 0.40 (Group III). The differences between the pretreatment groups and the control group were significant.

The time to maximal depression (mean \pm SEM) of the first twitch in the train-of-four response $\left(\mathrm{T}_{1}\right)$ was $230 \pm 10 \mathrm{sec}, 213 \pm 12 \mathrm{sec}$, and $325 \pm 11 \mathrm{sec}$ in Groups I, II, and III respectively. The differences between the pretreatment groups and the control group were significant.

In both studies the smaller pretreatment dose was associated with less alteration of the neuromuscular transmission. However, the smaller pretreatment doses afforded almost the same enhancement of action of a subsequent atracurium dose as the larger pretreatment doses.

No differences were observed in the train-of-four ratio between pancuronium or d-tubocurarine pretreatments at maximal neuromuscular blockade.

\section{Discussion}

Our results show that the neuromuscular blocking action of a small dose of atracurium in the adult 


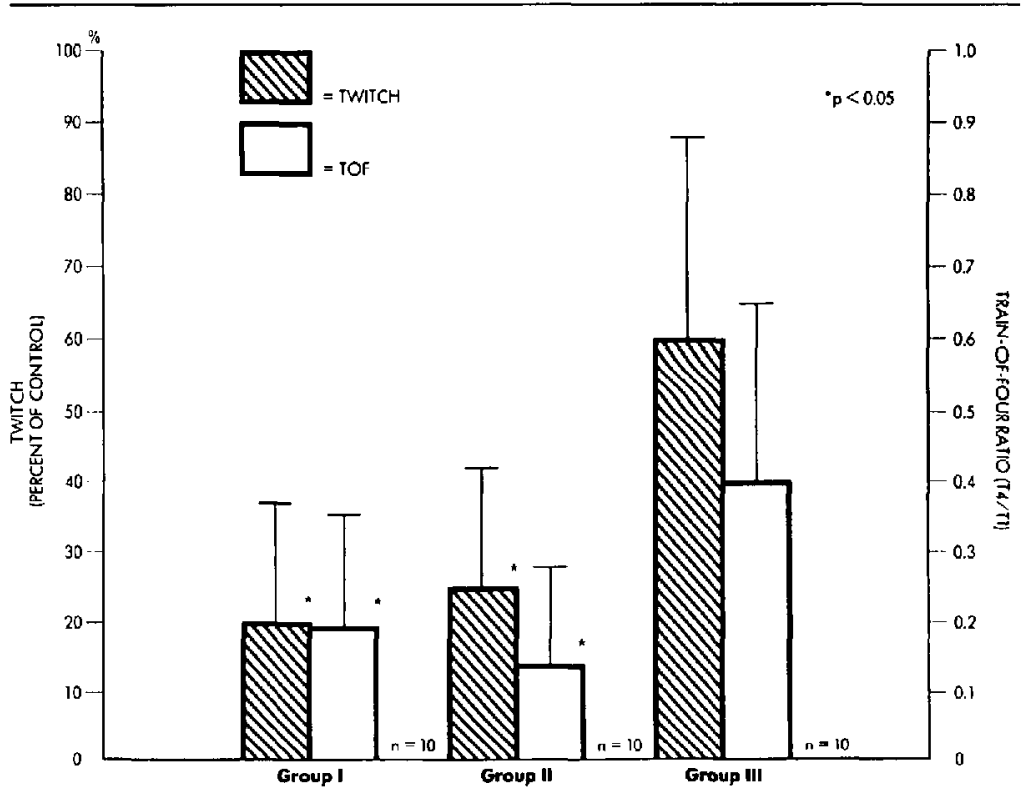

FIGURE 2 Extent of neuromuscular blockade after $0.1 \mathrm{mg} \cdot \mathrm{kg}^{-1}$ atracurium monitored by the evoked mechanical train-of-four response of the adductor pollicis muscle with and without d-tubocurarine pretreatment (Group I: $0.05 \mathrm{mg} \cdot \mathrm{kg}^{-1}$, Group II: $0.1 \mathrm{mg} \cdot \mathrm{kg}^{-1}$ ). Values are expressed as mean \pm SD "Indicates statistically significant difference from control (Group III).

jatient can be enhanced by pretreatment with either pancuronium or d-tubocurarine.

Considering the time from peripheral intravenous injection to maximal neuromuscular blockade (onset time), there was a significant shortening of the onset time in the $1 \mathrm{mg}$ pancuronium pretreatment group as well as in the d-tubocurarine pretreatment groups, compared with the control groups.

The $0.1 \mathrm{mg} \cdot \mathrm{kg}^{-1}$ atracurium bolus in the two control groups corresponded approximately to an $\mathrm{ED}_{35}-\mathrm{ED}_{40}$. This compares favourably with other studies employing evoked mechanical ${ }^{7,8}$ and elec-

TABLE III Effect of d-Tubocurarine (dTc) pretreatment on extent and time course of neuromuscular blockade after $0.1 \mathrm{mg} \cdot \mathrm{kg}^{-1}$ atracurium

\begin{tabular}{lllc}
\hline & $\begin{array}{l}\text { Group l } \\
\left(d T c=0.05 \mathrm{mg} \cdot \mathrm{kg}^{-1}\right)\end{array}$ & $\begin{array}{l}\text { Group II } \\
\left(d T c=0 . I \mathrm{mg} \cdot \mathrm{kg}^{-1}\right)\end{array}$ & $\begin{array}{l}\text { Group III } \\
\text { (control) }\end{array}$ \\
\hline $\begin{array}{l}\mathrm{T}_{4} \mathrm{~T}_{1} \text { ratio control } \\
\mathrm{T}_{4} \mathrm{~T}_{1} \text { ratio 3 minutes } \\
\text { after pretreatment }\end{array}$ & $0.98 \pm 0.03$ & $1.0 \pm 0.03$ & $0.99 \pm 0.02$ \\
$\begin{array}{l}\text { Maximal depression of } \\
\quad \mathrm{T}_{1}(\% \text { of control) }\end{array}$ & $20 \pm 17^{*}$ & $0.75 \pm 0.19^{*} \dagger$ & $1.0 \pm 0.02$ \\
$\begin{array}{l}\text { Maximal depression of } \\
\mathrm{T}_{4} / \mathrm{T}_{1} \text { ratio }\end{array}$ & $0.19 \pm 0.16$ & $25 \pm 17^{*}$ & $60 \pm 28$ \\
$\begin{array}{c}\text { Time to maximal } \\
\text { depression of } \mathrm{T}_{1}(\mathrm{sec})\end{array}$ & $230 \pm 28^{*}$ & $0.14 \pm 0.14^{*}$ & $0.40 \pm 0.25$ \\
\hline
\end{tabular}

Values are expressed as mean $\pm S D$.

*Significantly different $(p<0.05)$ from control (Group III).

$\dagger$ Significantly different $\left(p<0.05\right.$ from $T_{4} / T_{1}$ ratio control. 
tromyographic measurements. ${ }^{9}$ Although pretreatment with the smaller dose of either pancuronium or d-tubocurarine lacked almost any measurable effect of its own, it enhanced by 35-100 per cent the mechanical twitch and train-of-four inhibition following $0.1 \mathrm{mg} \cdot \mathrm{kg}^{-1}$ atracurium. As the equipotent pretreatment dose ${ }^{10}$ of either pancuronium or dtubocurarine corresponded to an $\mathrm{ED}_{5}-\mathrm{ED}_{15},{ }^{11,12}$ a purely additive effect would result in an $\mathrm{ED}_{40^{-}}$ $\mathrm{ED}_{55}$ drug effect. Yet the combined effect of pretreatment and atracurium resulted in an $\mathrm{ED}_{70^{-}}$ $\mathrm{ED}_{80}$ suggesting a synergistic action of the combination of the two drugs.

Pretreatment with a small dose of a non-depolarizing neuromuscular blocking drug such as dtubocurarine, ${ }^{13}$ gallamine or pancuronium has been used routinely to prevent or minimise some of the side effects of succinylcholine. However, even a small dose could have some significant neuromuscular blocking action and would thus be detrimental to the safety of the patient. In a volunteer study, comparing a $0.01 \mathrm{mg} \cdot \mathrm{kg}^{-1}$ dose with a 0.015 $\mathrm{mg} \cdot \mathrm{kg}^{-1}$ dose of pancuronium, a significant reduction of the train-of-four ratio with corresponding clinical signs such as difficulty in swallowing and breathing was observed at both dosages. ${ }^{14}$ Reduction in vital capacity, inspiratory force and peak expiratory flow was noticed at the higher dose. Similarly a wide variability of the response to a small dose of d-tubocurarine has been described. $^{15,16}$

In our study, the pretreatment doses of pancuronium or d-tubocurarine were administered after induction of anaesthesia and recording of baseline train-of-four responses and therefore the only method of judging the pretreatment's influence on neuromuscular transmission was by the twitch and the train-of-four ratio. Whereas there was no statistically significant difference between the twitch and the train-of-four ratio before and after pancuronium pretreatment, the $0.1 \mathrm{mg} \cdot \mathrm{kg}^{-1} \mathrm{~d}$ tubocurarine pretreatment produced significant changes in the train-of-four ratio. As the smaller dose $\left(0.05 \mathrm{mg} \cdot \mathrm{kg}^{-1}\right)$ of d-tubocurarine had the same synergistic effect with atracurium but was associated with only slight signs of neuromuscular blockade after three minutes, it seems to be preferable for further clinical trials.

The potentiation by pretreatment can only be achieved with a small dose of a different non- depolarising muscle relaxant drug ${ }^{17,18}$ as dividing the total dose of the same muscle relaxant has only additive effects. ${ }^{19}$ Two mechanisms could produce a synergistic (potentiating) action of two different non-depolarising muscle relaxants. Firstly, there is some evidence that the potentiating effect can best be achieved by combining a drug that has a definite prejunctional action with a drug that has a predominant postsynaptic action. ${ }^{20,21}$ Thus a mixture of d-tubocurarine and pancuronium is more effective than just the additive effects of the two compounds whereas a mixture of alcuronium and pancuronium has only an additive effect. ${ }^{20,22}$ The second mechanism is probably partial receptor occupancy as demonstrated by the small decrease of the train-offour ratio. That the potentiating action is most probably at the endplate, and not brought about indirectly by changes in the availability of free drug due to displacement from binding sites has been studied in vitro and in vivo. ${ }^{23}$

A pretreatment sequence that divides the total dose has been termed "priming principle." ${ }^{24}$ Dividing the total dose of atracurium, ${ }^{3,4}$ alcuronium, ${ }^{25}$ or pancuronium ${ }^{26}$ into a small pretreatment dose followed after some minutes by the remainder of the dose, can increase twitch depression significantly and shorten the onset time of maximal neuromuscular blockade as compared to the same dose given in a single injection. ${ }^{426}$ The mechanism of this phenomenon has not been explored but may be explained on the premise of partial receptor occupancy provided by the small initial dose.

Another factor that can influence the interaction of the pretreatment dose and the subsequent larger dose is the time interval. Because of the slower onset of action of non-depolarising muscle relaxants, the optimal time intervals identified for pretreatment before and after succinylcholine might not be applicable. ${ }^{13}$ In this study, the three-minute interval was chosen on the basis that the second larger dose needs at least one minute to reach the motor endplate resulting in an effective interval of four minutes as has been recommended earlier. ${ }^{14} \mathrm{~A}$ recent study using various pretreatment schemes found an optimal time interval of three to five minutes before the administration of a larger vecuronium dose. ${ }^{27}$

The quantification of the enhancement brought about by a combination of a pretreatment dose and a subsequent larger dose of a non-depolarising 
muscle relaxant is usually made in terms of shortening of onset time. ${ }^{5,24}$ Although onset time is a very important clinical characteristic of a muscle relaxant or a combination of muscle relaxants, the assessment of the neuromuscular properties should be made in terms of degree of neuromuscular blockade. Thus when investigating the effects of a pretreatment dose of a non-depolarising muscle relaxant and a subsequent larger dose, less than fully paralysing dosages should be used to judge the degree of enhancement. Only in this way is it possible to compare differences of pretreatment schedules which vary the pretreatment dose and the interval between pretreatment and full dose. The best regime found should then be studied with larger clinical dosages.

In conclusion, a pretreatment with either 0.007 $\mathrm{mg} \cdot \mathrm{kg}^{-1}$ of pancuronium or $0.05 \mathrm{mg} \cdot \mathrm{kg}^{-1}$ of $\mathrm{d}$ tubocurarine will enhance the action of a subsequent $0.1 \mathrm{mg} \cdot \mathrm{kg}^{-1}$ bolus of atracurium from an $\mathrm{ED}_{40}$ to an $\mathrm{ED}_{70}-\mathrm{ED}_{80}$.

\section{Acknowledgement}

Appreciation is extended to Mrs. Sarah Nevill for her diligent preparation of the manuscript.

\section{References}

1 Scott $R P F$, Goat VA. Atracurium: its speed of onset. A comparison with suxamethonium. $\mathrm{Br} \mathbf{J}$ Anaesth 1982; 54: 909-11.

2 Hunter JM, Jones RS, Utting JE. Use of atracurium during general surgery monitored by the train-offour stimuli. Br J Anaesth 1982; 54: 1243-50.

3 Gergis $S D$, Sokoll MD, Mehta $M$, Kemmotsu $O$, Rudd GD. Intubation conditions after atracurium and suxamethonium. Br J Anaesth 1983; 55: 83S865 .

4 Nagashima H, Nguyen HD, Lee S, Kaplan R, Duncalf $D$, Foldes $F F$. Facilitation of rapid endotracheal intubation with atracurium. Anesthesiology 1984; 61: A289.

5 Mehta MP, Choi WW, Gergis SD, Sokoll MD, Adolphson AJ. Facilitation of rapid endotracheal intubations with divided doses of nondepolarizing neuromuscular blocking drugs. Anesthesiology 1985; 62: 392-5.

6 Viby-Mogensen $J$. Clinical assessment of neuromuscular transmission. $\mathrm{Br} \mathrm{J}$ Anaesth 1982; 54: 209-23.
7 Basta SJ, Ali HH, Savarese JJ et al. Clinical pharmacology of atracurium besylate (BW 33A): a new non-depolarizing muscle relaxant. Anesth Analg 1982; 61: 723-9.

8 Gramsiad L, Lilleaasen $P$. Dose-response relation for atracurium, Org NC 45 and pancuronium. $\mathrm{Br}$ J Anaesth 1982; 54: 647-50.

9 Katz RL, Stirt J, Murray AL, Lee C. Neuromuscular effects of atracurium in man. Anesth Analg 1982; 61: 730-4.

10 Savarese JJ, Ali HH, Antonio RP. The clinical pharmacology of metocurine: dimethyltubocurarine revisited. Anesthesiology 1977; 47: 277-84.

11 Matteo RS, Brotherton WP, Nishitateno K, Khambatta HJ, Dias J. Pharmacodynamics and pharmacokinetics of metocurine in humans: comparison to d-tubocurarine. Anesthesiology 1982; 57: 183-90.

12 Shanks CA, Somogyi AA, Triggs EJ. Dose-response and plasma concentration-response relationships of pancuronium in man. Anesthesiology 1979; 51: III-8.

13 Horrow JC, Lambert DH. The search for an optimal interval between pretreatment dose of $d$ tubocurarine and succinylcholine. Can Anaesth Soc J 1984; 31: 528-33.

14 Howardy-Hansen $P$, Chraemmer J $\phi$ rgensen $B$, Ording H, Viby-Mogensen J. Pretreatment with nondepolarizing muscle relaxants: the influence on neuromuscular transmission and pulmonary function. Acta Anaesthesiol Scand 1980; 24: 419-22.

15 Pelikan EQ. Tether JE, Unna KR. Sensitivity of myasthenia gravis patients to tubocurarine and decamethonium. Neurology 1953; 3: 284-96.

16 Katz $R$. Muscle Relaxants. Amsterdam: Excerpta Medica, 1975, 320-2.

17 Duncalf D. Chaudhry I, Aoki T, Nagashima H, Foldes $F F$. Potentiation of pancuronium, vecuronium and atracurium by d-tubocurarine or metocurine. Anesthesiology 1983; 59: A292.

18 Foldes $F F$, Aoki $T$, Ono $K$, Duncalf D, Nagashima $H$. Potentiation of pancuronium, vecuronium and atracurium by d-tubocurarine and metocurine. Anesth Analg 1984; 63: 211.

19 Weinberg $G$, Stirt JA, Longnecker DE. Singlc versus divided doses of atracurium: does $0.05+$ 0.10 equal 0.15 ? Anesthesiology 1986; 64: 111-3. 
20 Pollard BJ, Jones RM. Interactions between tubocurarine, pancuronium and alcuronium demonstrated in the rat phrenic nerve-hemidiaphragm preparation. Br J Anaesth 1983; 55: 1127-30.

21 Bowman WC. Prejunctional and postjunctional cholinoceptors at the neuromuscular junction. Anesth Analg 1980; 59: 935-43.

22 Shanks $C A$. Dose-response curves for alcuronium and pancuronium alone and in combination. Anaesth Intensive Care 1982; 10: 248-51.

23 Martyn JAJ, Leibel WS, Matteo RS. Competitive nonspecific binding does not explain the potentiating effects of muscle relaxant combinations. Anaesth Analg 1983; 62: 160-3.

24 Schwarz S, llias W, Lackner F, Mayrhofer $O$, Foldes $F F$. Rapid tracheal intubation with vecuronium: the priming principle. Anesthesiology 1985; 62: 388-91.

25 Hutton P, Morgan G, El-Hassan K, Black AMS. Speeding the onset of neuromuscular block by alcuronium. Br J Anaesth 1983; 55: $918 \mathrm{P}$.

26 Bevan JC, Doherty WG, Breen PJ, Donati F, Bevan $D R$. Accelerated onset of pancuronium neuromuscular blockade with divided doses in infants and children. Anesthesiology 1984; 61: A312.

27 Taboada JA, Rupp SM, Miller RD. Redefining the priming principle for vecuronium during rapid sequence induction of anesthesia. Anesthesiology 1985; 63: A573.

\section{Résumé}

Chez 60 patients adultes devant subir une procédure chirurgicale, l' effer de "prêtraitement" au pancuronium ou à la d-tubocurarine avant un bolus d'atracurium de $0.1 \mathrm{mg} \cdot \mathrm{kg}^{-1}$ a été mesuré dans deux études séparées. Dans la première étude, les patients ont reçu soit $0.5 \mathrm{mg}$ (approximativement $0.007 \mathrm{mg} \cdot \mathrm{kg}^{-1}$ ) ou $1.0 \mathrm{mg}$ (approximativement $0.015 \mathrm{mg} \cdot \mathrm{kg}^{-1}$ ) de pancuronium ou du placebo (sérum physiologique isatonique) trois minutes avant l'injection d'atracurium $0.1 \mathrm{mg} \cdot \mathrm{kg}^{-1}$. Dans la deuxième étude, les patients ont rȩ̧u $0.05 \mathrm{mg} \cdot \mathrm{kg}^{-1}$ ou $0.1 \mathrm{mg} \cdot \mathrm{kg}^{-1}$ de d'tubocurarine ou un placebo. Le degré de blocage neuromusculaire a été évalué par le mécanogramme évoqué (muscle adducteur du pouce) utlisant une stimulation supramaximale de l'ondée-de-quatre (trainof-four). Les patients ayant reçu du pancuronium ou de la d' tubocurarine comme prétraitement (une dose égale à $E D_{5}-E D_{15}$ ) ont démontré une inhibition significativement plus grande du twitch $\left(E D_{70}-E D_{80}\right)$ ainsi que du rapport de l'ondée-de-quatre (train-of-four) comparativement au groupe placebo $\left(E D_{35}-E D_{40}\right)$. Un prétraitement avec des doses plus grandes de d-tubocurarine $\left(0.1 \mathrm{mg} \cdot \mathrm{kg}^{-1}\right)$ était associé avec un blocage neuromusculaire significatif. On conclut que le prétraitement avec du pancuronium ou de la d'tubocurarine potentialise l'action de $0.1 \mathrm{mg} \cdot \mathrm{kg}^{-1}$ d'atracurium chez l' homme d' environ 35-100 pour cent. 